\title{
HUBUNGAN KOMUNIKASI TERAPEUTIK DENGAN TINGKAT KECEMASAN PASIEN BARU di RUANG UGD PUSKESMAS TAMANAN BONDOWOSO
}

\author{
Rini Novita ${ }^{1}$, Setyo Adi Nugroho ${ }^{2}$, Yudho Tri Handoko \\ 1. Puskemas Tamanan Bondowoso, \\ Email : rininovita75@gmail.com \\ 2. Universitas Nurul Jadid Paiton Probolinggo \\ Email: setiyo666@gmail.com \\ 3. RSUD. Dr. Koesnadi Bondowoso
}

\section{Abstract}

One of the emotional problems disorders that are often encountered and has a psychological impact seriously is anxiety. Anxiety is an unclear and diffuse concern related to feelings of uncertainty and helplessness. Anxiety is an emotional experience that is short-lived and reasonable response, when individuals faceup pressure or events that threaten their lives, both internal and internal threats. Anxiety that happened and hav a relation ship with medical condition often found when patient came to healt hfacility, whichone of themisemergencyroom. Therapeutic communication methods provide understanding between nurses and patients with the aim of helping patients clarify and reduce the burden of the mind and are expected to eliminate anxiety. This study aims to knowabout relationship between therapeutic communication and the anxiety level of new patients.This study useddescription korelation with cross sectional approach. Sample are 171 people. Instrument used for data collection is the questionnaire, anddata analysis used the Spearman Rho test. Therapeutic communication 
of nurses was mostly in good categorywas 128 respondents $(74.9 \%)$. The anxiety level of new patients is not anxious categorywere 127 respondents (74.3\%). Rho Spearman's test results obtained a coefficient (r) of 0.901 with a $p$ value of 0,000 . Because $p<0.005$ then $\mathrm{HO}$ is rejected.Conclusion, There is a significan trelation ship between therapeutic communication and the anxiety level of new patients in the emergency room at Tamanan Bondowoso Public Health Center.

Key Words: therapeutic communication, anxiety level, patient, emergency room

\section{Abstrak}

Salah satu masalah gangguan emosional yang sering ditemui dan menimbulkan dampak psikologis serius adalah kecemasan. Kecemasan adalah kekhawatiran yang tidak jelas dan menyebar berkaitan dengan perasaan tidak pasti dan tidak berdaya. Kecemasan merupakan pengalaman emosional yang berlangsung singkat dan merupakan respon yang wajar, pada saat individu menghadapi tekanan atau peristiwa yang mengancam kaehidupannya baik itu ancaman eternal dan internal. Terjadinya gejala kecemasan yang berhubungan dengan kondisi medis sering ditemukan saat pasien mendatangi fasilitas kesehatan, salah satunya ruang UGD. Metode komunikasi terapeutik memberikan pengertian antara perawat dan pasien dengan tujuan membantu pasien memperjelas dan mengurangi beban pikiran serta diharapkan dapat menghilangkan kecemasan.Penelitian ini bertujuan untuk mengetahui hubungan komunikasi terapeutik dengan tingkat 
kecemasan pasien baru. Penelitian ini menggunakan deskriptif korelasi dengan pendekatan cross sectional. Sampel penelitian berjumlah 171 orang. Alat ukur yang digunakan untuk pengumpulan data yaitu kuesioner, analisis data menggunakan uji rho spearman. Komunikasi terapeutik perawat sebagian besar kategori baik, yaitu sebanyak 128 responden (74,9\%). Tingkat kecemasan pasien baru kategori tidak cemas yaitu sebanyak 127 responden (74,3\%). Hasil uji Rho Spearman diperoleh nilai koefisien (r) sebesar 0,901 dengan $p$ value sebesar 0,000. Karena $\mathrm{p}<0,005$ maka HO ditolak. Kesimpulan, Terdapat hubungan yang signifikan antara komunikasi terapeutik dengan tingkat kecemasan pasien baru di ruang UGD Puskesmas Tamanan Bondowoso.

Kata Kunci : Komunikasi Terapeutik, Kepuasan Pasien. 


\section{Pendahuluan}

Salah satu masalah gangguan emosional yang sering ditemui pada masyarakat dan menimbulkan dampak psikologis cukup serius adalah ansietas (kecemasan). Kecemasan adalah kekhawatiran yang tidak jelas dan menyebar berkaitan dengan perasaan tidak pasti dan tidak berdaya. Keadaan emosi ini tidak memiliki objek yang spesifik, dialami secara subyektif dan dikomunikasikan secara interpersonal (Stuart, Laraia, 2005). Menurut Tirto Djiwo (2012) yang dikutip oleh Tumbuan (2015) dalam beberapa kasus, kecemasan disebabkan oleh kondisi medis yang memerlukan perawatan. Kecemasan atau ansietas adalah perasaan kuatir yang berlebihan dan tidak jelas, juga merupakan suatu respons terhadap stimuli eksternal maupun internal yang menimbulkan gejala emosional,kognitif fisik, dan tingkah laku (Badero. M. 2015).
Federasi Dunia untuk Kesehatan Jiwa tahun 2011 mencanangkan seruan untuk mendorong investasi di bidang kesehatan jiwa. Masalah gangguan kesehatan jiwa berupa gangguan kecemasan dan depresi pada orang dewasa secara nasional mencapai 11,6\%. Investasi dibidang kesehatan jiwa diperlukan untuk menekan prevalensi (Siswarini and Agustin, Yuana Dwi 2019).

Menurut hasil Riset Kesehatan Dasar (Riskesdas) terkait dengan gangguan kecemasan pada tahun 2013 menunjukkan bahwa sebesar 6\% untuk usia 15 tahun ke atas atau sekitar 14 juta penduduk di Indonesia mengalami gangguan mental emosional yang ditunjukkan dengan gejala-gejala kecemasan dan depresi. 7,5\%, penduduk provinsi jawa timur mengalami gangguan mental emosional pada penduduk berumur 15 tahun ke atas (berdasarkan Self Reporting Questionnaire20) provinsi jawa timur 
(TurnianiLaksmiarti.

2013).

Kecemasan merupakan pengalaman emosional yang berlangsung singkat dan merupakan respon yang wajar, pada saat individu menghadapi tekanan atau peristiwa yang mengancam kaehidupannya baik itu ancaman eternal dan internal. Prevalensi gangguan kecemasan saat dibawa ke Unit Gawat Darurat (UGD) berkisar pada angka 6-7\% dari populasi umur (perempuan lebih banyak dibandingkan laki-laki). ${ }^{1}$ Terjadinya gejala kecemasan berhubungan yang medis umum sering ditemukan, walaupun insidensi gangguan variasi untuk masing-masing kondisi medis umum tidak spesifik (Stuart,G.W 2006).

Berdasarkan penelitian sebelumnya yang dilakukan oleh Mohamat Iskandar di Rumah Sakit RAA Soewondo Pati didapatkan Dua puluh dua responden mengalami kecemasan sedang sebelum

kesehatan.

pendidikan

pendidikan kesehatan,

hanya 17 responden mengalami kecemasan ringan. Tes Wilcoxon memperoleh perbedaan rata-rata tingkat kecemasan sebelum dan sesudah pendidikan kesehatan adalah 0,49 dengan perbedaan standar deviasi 0,077 dan p-value 0,001 yang berarti ada perbedaan signifikan tingkat kecemasan sebelum dan sesudah pendidikan kesehatan (Mohamat Iskandar. 2015). $\mathrm{Hal}$ tersebut diperkuat dengan penelitian yang dilakukan Mujiati Rohmah dan Siti Nur Qomariyah di High Care Unit Rumah Sakit Muhammadiyah Gresik didapatkan hasil kecemasan nilai $\mathrm{a}=0,000$ yang berarti bahwa $a<0,05$ maka ada pengaruh antara komunikasi terapeutik terhadap tingkat kecemasan keluarga pasien kritis (MujiatiRohmah).

Sebagian besar pasien masuk ke Rumah Sakit dengan persiapan atau sudah direncanakan, dimana klien sudah mempersiapkan segala 
sesuatu

berhubungan

keperluan - keperluan selama dirawat di Rumah Sakit. Tetapi sebagian besar klien masuk tanpa persiapan dan tanpa perencanaan sebelumnya atau masuk ke Rumah Sakit dalam keadaan darurat. Meskipun demikian dengan cara apapun klien masuk Rumah sakit ia akan merasa takut dan cemas. Fenomena seperti ini bagi perawat adalah hal yang biasa, tetapi bagi klien dan keluarganya merupakan hal yang menakutkan dan aneh. Oleh karena itu menerima pasien baru perlu dilakukan orientasi (Arline. 2007).

Kurangnya komunikasi antara staf rumah sakit dengan pasien dan keluarga merupakan salah satu alasan komplain lain pasien dan keluarga selama dirawat di di rumah sakit. Hal ini disebabkan karena kurang disadari pentingnya komunikasi oleh perawat dan rendahnya pengalaman perawat akan teori, konsep dan arti penting komunikasi terapeutik dalam memberikan asuhan keperawatan. Pasien yang dirawat di Ruang High Care Unit, terutama pasien yang mengalami keadaan gawat yang dapat mengancam kehidupan. Kondisi seperti ini menimbulkan ketakutan dan kecemasan yang meningkat pada pasien dan keluarganya (PH, L, Keliat, B. A and Putri, Y. S. 2016).

Komunikasi terapeutik dapat menjadi jembatan penghubung antara perawat sebagai pemberi pelayanan dan pasien sebagai pelayanan.

pengguna Komunikasi terapeutik dapat mengakomodasi pertimbangan status kesehatan yang dialami pasien. Komunikasi terapeutik memperhatikan pasien secara holistik, meliputi aspek keselamatan, menggali penyebab dan mencari jalan terbaik atas permasalahan pasien. Juga mengajarkan caracara yang dapat dipakai untuk mengekspresikan kemarahan yang dapat diterima oleh semua pihak tanpa harus merusak (asertif). Komunikasi 
terapeutik memberikan pengertian antara perawat-klien dengan tujuan membantu klian memperjelas dan mengurangi beban pikiran serta diharapkan dapat menghilangkan kecemasan (Mulyani S, etal. 2008).

Perawat sebagai

komponen penting dalam proses keperawatan dan orang yang terdekat dengan klien diharapkan mampu berkomunikasi terapeutik, melalui pendekatan, perbuatan, atau ekspresi yang memfasilitasi

penyembuhan

klien. Komunikasi sebagai elemen terapi mempunyai makna bahwa komunikasi yang dilakukan perawat adalah mempunyai tujuan terapi atau memberikan efek penyembuhan buat klien, senyum perawat, kesabaran, kelembutan, kata-kata yang tegas dan menyejukkan atau katakata yang disampaikan dengan jelas dapat mempengaruhi perilaku klien untuk berbuat lebih baik dalam rangka meningkatkan derajat kesehatannya (Tri Anjaswarni, S.Kp., M.Kep 2016).
Berdasarkan data yang diperoleh di UGD Puskemas Tamanan, Bondowoso tercatat jumlah pasien selama bulan Desember 2018 sampai dengan Februari 2019 sebanyak 947 pasien. Dengan pembagian 300 pasien di bulan Desember 2018, 320 pasien di bulan Januari 2019, dan 327 pasien di bulan Februari 2019.

Banyaknya pasien yang datang ke Puskesmas Tamanan melalui UGD menuntut adanya komunikasi yang baik anatara perawat-klien secara maksimal dengan tujuan mengurangi tingkat kecemasan. Salah satu metode untuk mengurangi tingkat kecemasan adalah dengan komunikasi terapeutik, hal inilah yang melatarbelakangi penulis untuk meneliti hubungan komunikasi terapeutik dengan tingkat kecemasan pasien di ruang UGD puskesmas Tamanan, Bondowoso.

Tujuan dari penelitian ini adalah untuk Mengetahui hubungan antara komunikasi terapeutik dengan Tingkat kecemasan Pasien baru di 
ruang UGD puskesmas tamanan Bondowoso.

\section{Metode}

Desain penelitian yang digunakan dalam penelitian ini adalah deskriptif korelasi, dengan desain penelitian cross sectional. Penelitian dilakukan di ruang UGD Puskesmas Tamanan, Bondowoso dengan waktu pelaksanaan pada tanggal 22 April 2019 sampai dengan 22 Mei 2019.

Populasi dalam penelitian ini adalah semua pasien yang mendapatkan pelayanan di UGD puskemas Tamanan dengan rata rata kunjungan 300 orang per bulan. Dengan sampel semua pasien dewasa yang mendapatkan pelayanan di UGD Puskesmas Tamanan dengan teknik purposive samplings sebanyak 171 orang dengan kriterian penelitian : bersedia menjadi responden, klien berada dalam kondisi sadar penuh, klien bisa membaca.Pengukuran variabel menggunakan kuesioner terapeutik sebanyak 20 pertanyaan tertutup dengan pilihan jawabab "YA" atau "TIDAK" dan kuesioner tingkat kecemasan ZSAS dengan jumlah pertanyaan tertutup sebanyak 20 pertanyaan.

Pengolahan data dilakukan setelah seluruh data terkumpul . data yang sudah lengkap kemudian dibuat koding. Koding dibuat dalam tabel dan selanjutnya dilakukan entry data ke program SPSS di komputer.

Setelah memperoleh nilai dari masing-masing tabel selanjutnya data dianalisa dengan computer SPSS versi 15. dilakukan terhadap dua variabel yang diduga berhubungan atau berkorelasi. Data yang diperoleh dalam bentuk ordinal dianalisa dengan menggunakan uji Spearman. Uji ini dimaksudkan untuk mengetahui seberapa besar hubungan antara komunikasi terapeutik dengan tingkat kecemasan dengan tingkat signifikan $\mathrm{a}<0,05$ bila hasil analisis $\mathrm{p} \leq 0,05$ artinya ada hubungan antara komunikasi terapeutik dengan tingkat kecemasan. 


\section{Hasil}

Data Karakteristik Umum Responden

Tabel 1 Karakteristik responden berdasarkan umur

\begin{tabular}{|c|c|c|c|c|c|c|}
\hline $\begin{array}{l}\text { Um } \\
\text { ur }\end{array}$ & $\mathrm{N}$ & $\begin{array}{c}\text { Ran } \\
\text { ge }\end{array}$ & $\begin{array}{c}\mathrm{Mi} \\
\mathrm{n}\end{array}$ & $\begin{array}{c}\mathrm{Ma} \\
\mathrm{ks}\end{array}$ & $\begin{array}{l}\mathrm{Me} \\
\text { an }\end{array}$ & $\begin{array}{l}\text { Std. } \\
\text { Dev }\end{array}$ \\
\hline $\begin{array}{l}\text { res } \\
\text { pon }\end{array}$ & 171 & 59 & 15 & 74 & $\begin{array}{r}33 . \\
61\end{array}$ & $\begin{array}{r}12.3 \\
76\end{array}$ \\
\hline
\end{tabular}

Sumber : data kuesioner 22 April 2019-22 Mei 2019

$\quad$ Dari tabel 1 di atas
dapat diketahui bahwa
nilai rata-rata umur
adalah 33,61 dengan nilai
terendah adalah 15, dan
nilai tertinggi adalah 74.

Tabel 2 Distribusi frekuensi responden berdasarkan Jenis Kelamin

\begin{tabular}{lcc}
\hline $\begin{array}{c}\text { Jenis } \\
\text { Kelamin } \\
\text { Responden }\end{array}$ & $\begin{array}{c}\text { Frekuensi } \\
(\mathrm{N}=171)\end{array}$ & $(\%)$ \\
\hline Laki - laki & 68 & 39.8 \\
Perempuan & 103 & 60.2 \\
\hline Total & 171 & 100.0 \\
\hline
\end{tabular}

Sumber : data kuesioner 22 April 201922 Mei 2019

Dari tabel 2 diatas dapat diketahui bahwa jumlah responden laki-laki sebanyak 68 orang $(39,8 \%)$ dan jumlah responden perempuan sebanyak 103 orang $(60,2 \%)$

\section{Tabel 3 Distribusi}

Karakteristik Responden Berdasarkan Tingkat Pendidikan

\begin{tabular}{lcc}
\hline $\begin{array}{c}\text { Tingkat } \\
\text { Pendidikan } \\
\text { Responden }\end{array}$ & $\begin{array}{c}\text { Frekuensi } \\
(\mathrm{N}=171)\end{array}$ & $(\%)$ \\
\hline SD & 69 & 40.4 \\
SMP & 45 & 26.3 \\
SMA & 49 & 28.7 \\
Perguruan & 8 & 4.7 \\
Tinggi & 171 & 100.0 \\
\hline Total & 17
\end{tabular}

Sumber : data kuesioner 22 April 2019-22 Mei 2019

Dari tabel 3 dapat diketahui bahwa tingkat pendidikan responden paling banyak yaitu SD 69 orang $(40,4 \%)$.

Tabel4DistribusiFrekuensi RespondenTingkat KecemasanPadaPasienBar u di Ruang UGD PuskesmasTamananBondo woso

\begin{tabular}{lcc}
\hline $\begin{array}{c}\text { Tingkat } \\
\text { Kecemasan }\end{array}$ & Frekuensi & $\%$ \\
\hline $\begin{array}{c}\text { Tidak } \\
\text { cemas } \\
\begin{array}{c}\text { Kecemasan } \\
\text { ringan }\end{array}\end{array}$ & 127 & 74.3 \\
& 24 & 14.0
\end{tabular}




\begin{tabular}{|c|c|c|}
\hline $\begin{array}{l}\text { Kecemasan } \\
\text { sedang }\end{array}$ & 18 & 10.5 \\
\hline $\begin{array}{l}\text { Kecemasan } \\
\text { berat }\end{array}$ & 2 & 1.2 \\
\hline Total & 171 & 100.0 \\
\hline
\end{tabular}

Sumber : data kuesioner 22 April 2019-22 Mei 2019

Tabel 4 di atas diketahui bahwa tingkat kecemasan pasien paling banyak adalah tidak cemas sebanyak 127 orang $(74,3 \%)$, dan paling sedikit tingkat kecemasan berat sebanyak 2 orang $(1,2 \%)$

\begin{tabular}{lcr}
$\begin{array}{l}\text { Tabel } \\
\text { Frekuensi }\end{array}$ & \multicolumn{2}{r}{$\begin{array}{r}\text { Distribusi } \\
\text { Komunikasi }\end{array}$} \\
$\begin{array}{l}\text { Pada Pasponden } \\
\text { Ruang }\end{array}$ & $\begin{array}{r}\text { Terapeutik } \\
\text { Baru di }\end{array}$ \\
$\begin{array}{l}\text { PuskesmasTamanan } \\
\text { Bondowoso }\end{array}$ & UGD \\
$\begin{array}{l}\text { Bonunikasi } \\
\text { Komupeutik }\end{array}$ & Frekuensi & $(\%)$ \\
\hline $\begin{array}{c}\text { Baik } \\
\text { Cukup }\end{array}$ & 128 & 74.9 \\
$\begin{array}{c}\text { baik } \\
\text { Kurang } \\
\text { baik }\end{array}$ & 35 & 20.5 \\
\hline Total & 8 & 4.7 \\
\hline
\end{tabular}

Sumber : data kuesioner 22 April 2019 - $22 \mathrm{Mei}$ 2019

Pada tabel 5 diketahui bahwa komunikasi terapeutik perawat dinilai sudah baik oleh 128 responden $(74,9 \%)$.

Tabel 6 Tabulasi Silang Hubungan Komunikasi Terapeutik Dengan Tingkat Kecemasan

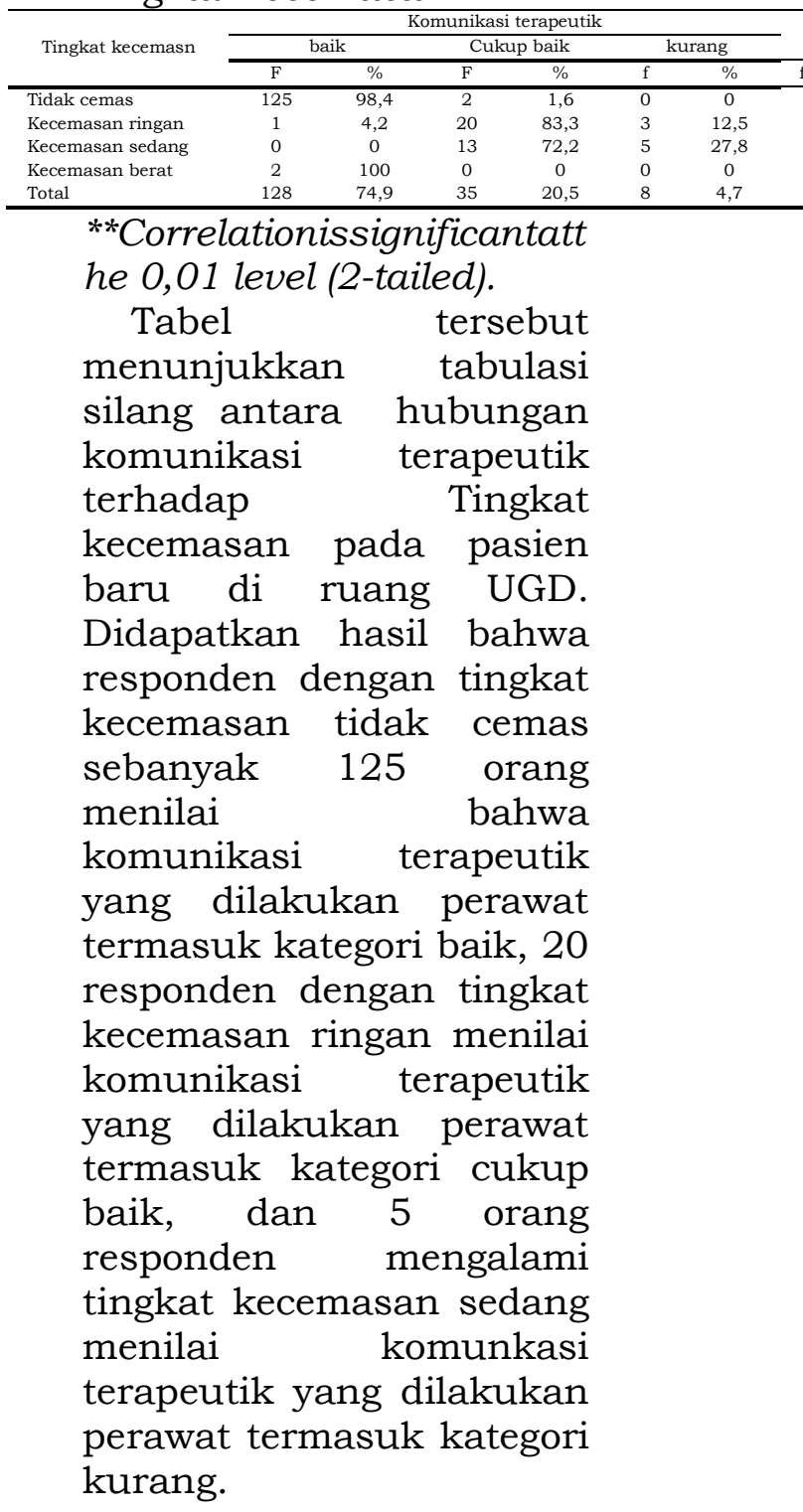


Hasil uji statistic korelasi Rho Spearman's didapatkan bahwa nilai $\mathrm{p}$ sebesar 0,000. Karena nilai $\mathrm{p}<0,05$ maka $\mathrm{HO}$ ditolak dan $\mathrm{H} 1$ diterima, yang menyatakan bahwasanya ada hubungan antara komunikasi terapeutik dan tingkat kecemasan pada pasien baru di ruang UGD PuskesmasTamanan Bondowoso

\section{PEMBAHASAN}

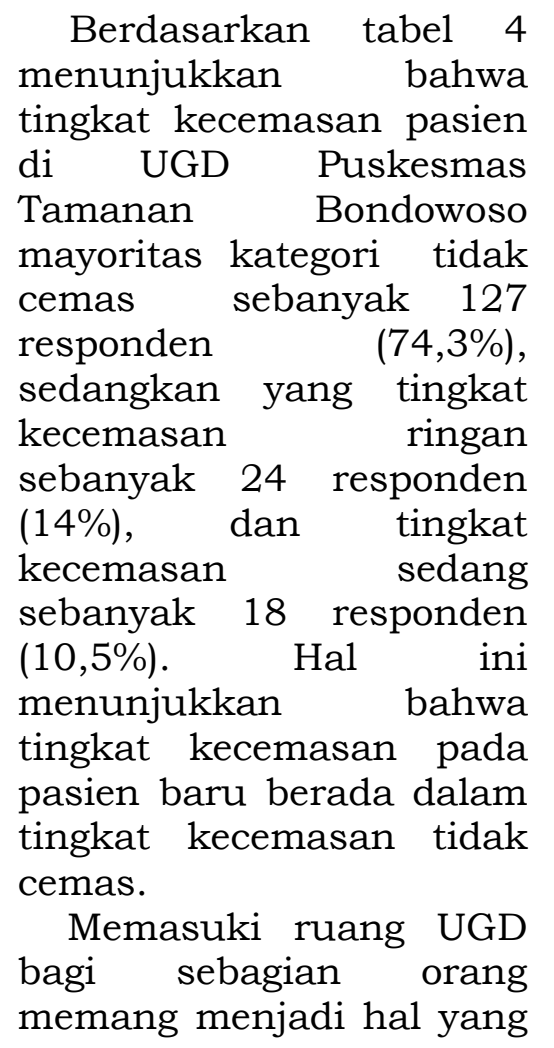

menakutkan sehingga menimbulkan kecemasan. Akan tetapi, hal tersebut bisa diminimalisir karena petugas UGD PuskesmasTamanan telah menerapkan komunikasi terapeutik sejak pasien datang hingga pasien pulang maupun pindah ruangan ke ruang rawat inap. Penerapan aturan baku berupa SOP penerimaan pasien, ketersediaan sarana dan prasarana, perawat yang kompeten, serta dokter jaga UGD yang siaga 24 jam juga ikut mendukung terlaksananya komunikasi terapeutik di ruang UGD PuskesmasTamanan.

Pasien saat masuk rumah sakit maupun klinik sebelum diberikan orientasi seringkali mengalami kecemasan. kecemasan ini tidak hanya dialami oleh pasien tapi juga oleh keluarga. Hal ini dapat disebabkan karena ketidaktahuan tentang kegiatan yang ada di rumah sakit dan memerlukan penjelasan lebih lanjut. Perawat merupakan bagian dari lingkungan, yang kemudian membantu pasien untuk beradaptasi, 
dengan menginformasikan kepadan pasien tentang tindakan yang akan dilakukan, membantu pasien meningkatkan pengetahuannya sehingga rasa cemas bisa ditekan bahkan mungkin bisa dihilangkan. Hal ini sesuai dengan pendapat Asmadi (2009) yang menyebutkan bahwa perawat merupakan sumber daya yang tersedia di lingkungan rumah sakit yang pengetahuan ketrampilan membantu mempunyai dan mengembalikan untuk pasien mencapai ke seimbangan diri dalam menghadapi lingkungan yang baru.

Berdasarkan tabel 3, tingkat pendidikan pasien yang berobat ke UGD Puskesmas Tamanan yang rata rata berpendidikan SMP dan SMA juga ikut berperan mengurangi dalam kecemasan. Fakta di lapangan tersebut sesuai dengan Jatman (2000) yang mengatakan bahwa "Tingkat pendidikan yang cukup akan lebih mudah dalam mengidentifikasi stresor dalam diri sendiri maupun dari luar dirinya.
Tingkat pendidikan juga mempengaruhi kesadaran dan pemahaman terhadap stimulus". Pendidikan seseorang berperan dalam membentuk sikap dan perilaku seseorang dalam berinteraksi dengan seseorang. Pendidikan seseorang yang meningkat mengajarkan individu mengambil sikap keputusan yang terbaik untuk dirinya

Berdasarkan tabel 5, diketahui bahwa mayoritas responden berpendapat bahwa perawat telah baik melakukan komunikasi terapeutik pada pasien baru di ruang UGD PuskesmasTamanan

Bondowoso sebanyak 128 responden (74,9\%).

Faktor karakteristik perawat memegang peranan penting dalam melakukan komunikasi terapeutik. Di ruang UGD PuskesmasTamanan, latar belakang pendidikan perawat terdiri dari 8 orang DIII Keperawatan dan 2 orang S1 keperawatan, demikian juga dengan pengalaman lama kerja rata-rata telah bekerja lebih dari 5 tahun. berdasarkan karakteristik 
perawat tersebut, peneliti meyakini bahwa perawat di ruang UGD PuskesmasTamanan dapat berkomunikasi dengan baik.

Komunikasi terapeutik dikatakan baik bila perawat bekerja sama dengan pasien mendiskusikan tentang masalah yang sedang dihadapi untuk pencapaian tujuan tindakan keperawatan, perawat memberi informasi tentang tindakan keperawatan yang akan dilakukan dan melakukan evaluasi hasil tindakan keperawatan terhadap pasien. Kondisi saling membutuhkan antara perawat-pasien, pasienperawat yang dilaksanakan secara terapeutik akan menghasilkan output yang baik dan secara tidak langsung bisa menekan tingkat kecemasan. Selain itu, status

PuskesmasTamanan yang telah terakreditasi juga ikut berperan dalam membuat peraturan dan SPO yang wajib dilaksanakan oleh semua karyawan yang ada di dalamnya, termasuk cara tata cara menerima pasien baru di ruang UGD, sehingga dengan adanya SOP yang berlaku, diharapkan pasien yang datang akan merasa nyaman dan tenang serta tidak merasa takut.

Hasil penelitian yang mendukung dilakukan oleh Khotimah (2010) menyatakan bahwa dari 96 responden mengatakan komunikasi terapeutik baik sebanyak 70 orang (72,9\%). Komunikasi sangat penting khususnya komunikasi antara perawat - klien dimana dalam komunikasi ini perawat dapat menemukan beberapa solusi dari permasalahan yang sedang dialami klien.

Penelitian ini sejalan dengan penelitiannya Priscylia (2014) menunjukkan bahwa pada fase kerja adalah baik sebanyak 60 orang $(89,6 \%)$. Hal ini terjadi karena pada fase kerja perawat - pasien memiliki waktu bertatap muka lebih lama dan perawat mendengarkan secara aktif dengan penuh 
perhatian

mampu

pasien

mendefinisikan

kesehatannya.

Hasil penelitian ini menunjukkan

hubungan

signifikan

komunikasi

perawat dengan tingkat kecemasan pasien di di UGD PuskesmasTamanan Bondowoso. Dengan nilai signifikasi (p) 0,000, maka dapat dikatakan bawhwa komunikasi terapeutik memberikan pengaruh yang signifikasn terhadap tingkat kecemasan.

Proses komunikasi berlangsung sejak pasien datang hingga mamasuki proses anamnesa, pasien umumnya mengekspresikan keluhan dan ketakutannya akan penyakit yang dideritanya, begitu juga keluarga pasien. Mereka akan merasa senang jika keluhan yang mereka utarakan didengarkan dan mendapatkan simpati dari petugas UGD. Akan tetapi jika petugas terkesan acuh tak acuh dalam menangani pasien, pasien akan cenderung tertutup, dan tidak mengutarakan keluhannya secara keseluruhan. Pasien yang baru datang, memerlukan pendampingan, bantuan, serta motivasi dari perawat. Penyampaian informasi kepada pasien yang datang hingga proses tindakan keperawatan dengan menggunakan bahasa yang mudah dipahami (bahasa madura) oleh perawat terhadap pasien membantu menciptakan komunikasi yang intens dan baik. Dengan meningkatkan hubungan antara perawat - pasien serta pasien perawat bisa menekan tingkat kecemasan ke tingkatan yang lebih rendah, atau bahkan mungkin bisa hilang.

Hal ini sesuai dengan pendapat Atkinson (1992) yang mengatakan bahwa interaksi antara perawat dan pasien dapat meningkatkan mekanisme koping dan memberi dukungan emosional kepada pasien yang mengalami kecemasan dan rasa takut. Salah satu faktor eksternal yang mempengaruhi kecemasan pasien adalah adanya komunikasi dan sikap secara terapeutik yang 
dilakukan perawat ketika berinteraksi

kepada pasien, sehingga tingkat kecemasan pada setiap pasien akan menurun jika komunikasi dan sikap terapeutik perawat dilaksanakan dengan baik. Selain itu adanya komunikasi yang dilakukan perawat dengan menginformasikan

prosedur pelayanan saat di UGD (persiapan pasien, obat-obatan, dan jenis tindakan) dan hal-hal lain di luar tindakan medis mampu membantu mengurangi tingkat kecemasan, hal ini sejalan dengan penelitian yang dilakukan oleh MujiatiRohmah yang menyatakan bahwa komunikasi terapeutik dapat menurunkan kecemasan pasien dan keluarga pasien kritis. perawat dapat mengaplikasikan

komuniksi terapeutik sebagai intervensi mandiri dalam usaha menurunkan kecemasan pasien dan keluarga.

\section{SIMPULAN}

\section{Komunikasiterapeutikp erawatpadapasienbaru}

di ruang UGD

PuskesmasTamananter masukdalamkategoribai ksejumlah 128 orang (74,9\%).

2. Gambarantingkatkecem asanpasienbaru di ruang UGD PuskesmasBondowosote rmasukdalamkategoritid akcemassejumlah 125 orang $(73,1 \%)$

3. Ada

hubunganantaraKomun ikasiterapeutikdenganti ngkatkecemasanpasien baru di ruang UGD PuskesmasTamananBo ndowosodengannilaikor elasi rho spearman sebesar $\quad 0,901$ dengannilai sig. $\quad(2$ tailed) sebesar 0,000 atau< 0,05.

\section{DAFTAR PUSTAKA}

A.H Yusuf 2014, Buku Ajar Keperawatan Kesehatan Jiwa, Salemba Medika

Agustin, I. M. (2009). Hubungan

Pelaksanaan

Komunikasi

Terapeutik Dengan Tingkat Kecemasan Pasien Rawat Inap di BP RSUD Kebumen. 
Ilmiah Kesehatan

Keperawatan. 5, 143 152 .

Arifah, S \&Nuriala, I. (2012). Pengaruh

Pemberian Informasi

Tentang Persiapan

Operasi

Dengan

Pendekatan

Komunikasi

Terapeutik Terhadap

Tingkat Kecemasan

Pasien Pre Operasi di

Ruang Bougenville

RSUD Sleman.Jurnal

Kebidanan. IV, 140 219.

Arline (2007), Belajar

Merawat di Bangsal

Penyakit Dalam,

Jakarta : Penerbit

Buku Kedokteran EGC Asmadi. 2009 Mengatasi Rasa Cemas. Surabaya : Putra Belajar

Baradero,M., Dayrit,

M.W., Siswadi, Y., Ariani, F., Ester,

M. (2008).

KeperawatanPerioperat

if : Prinsip dan

Praktik. Jakarta : EGC.

Berita Ilmu Keperawatan ISSN 1979-2697, Vol . 1 No.2 1, Maret 2008 : 1-6

Br. J med Psychol 1959.Hamilton M.The assesment of anxiety states by rating

Dahlan, Sopiyudin, 2011, Statistik Untuk Kedokteran dan Kesehatan Edisi 5, Jakarta, Salemba Medika.

Damayanti, M.N. (2008). Teori Komunikasi Analisis dan Aplikasi. Jakarta: Salemba Humanika.

H. Syamsunie Carcel HR, 2018, Metodologi Penelitian Kesehatan Dan Pendidikan, Yogyakarta, Penebar Media Pustaka: 96.

Handono, 2019. Buku Pedoman Penulisan Skripsi, Program Studi Keperawatan Fakultas Kesehatan UNUJA; 9

Hawari. (2008). Manajemen Stress Cemas dan Depresi. Jakarta: FKUI.

https://dokumen.tips/doc uments/caramengukur-tingkatkecemasan.htmldiakse s pada 27 Maret 2019; 22.53diakses pada 27 Maret 2019; 22.53

Ina, Wahyu. (2010). Asuhan

KeperawatanJiwa.Jogj akarta: Nuha Medika. 
Jatman, D. 2000.

Pendidikan bagi orang

sakit. Bandung:

Rosadakarya

Kaplan, H.I and Saddock, BJ. 1998 Keperawatan Kritis Pendekatan Holistik. Jakarta EGC Kusumawati, F. Hartono, Y. 2010. Buku Ajar Keperawatan Jiwa. Jakarta : Salemba Medika

Mohamat Iskandar, The Effect of Health Education in Surgery Preparation to Anxiety Level of Patiens With Pre Herniorrhaphy in RAA Soewondo Hospital Pati

Mujiati Rohmah, Siti Nur Qomariah 2017, Komunikasi terapeutik perawat menurunkan kecemasan keluarga pasien kritis. Fakultas ilmu Kesehatan Universitas Gresik.

Mulyani S, et al. Komunikasi dan Hubungan Terapeutik Perawat-Klien

terhadap Kecemasan Pra-Bedah Mayor. Jurnal. Yogyakarta; 2008.

Mulyani, S., Paramastri, I., Priyanto, M.A. (2008). Komunikasi dan Hubungan

Terapeutik PerawatKlien Terhadap kecemasan Pra Bedah Mayor. Berita Kedokteran

Masyarakat. 24, 151155.

Ns. Rika Safrika, S.Kep,.M.Kep dkk, 2018, Buku Ajar Keperawatan Dasar 2 Komunikasi terapeutik Dalam Keperawatan, Padang, Andalas University Press.

Ns. Rika Sarfika, S.Kep., M.Kep 2018. Buku Ajar Keperawatan Dasar 2, Andalas University Press

Nurhalimah, NS, 2016. Buku Ajar Keperawatan Jiwa, Kementrian Kesehatan Republik Indonesia

Nurjanah.

(2001).

Komunikasi

Keperawatan : Dasar

- Dasar Komunukasi

Bagi Perawat. Cetakan

: 1. Yogyakarta : Moco Medika.

Nursalam, 2008. Konsep \& Metode Keperawatan (ed.2). salemba Medika;

Nursalam. (2014). Metodologi Penelitian Ilmu Keperawatan: 
Pendekatan Praktis

(3rd ed.). Jakarta:

Salemba Medika.

$\mathrm{PH}, \mathrm{L}$, Keliat, B. A and Putri, Y. S. 2016.

Penurunan Tingkat Ansietas Klien

Penyakit Fisik Dengan Terapi Generalis Ansietas di Rumah Sakit Umum Bogor, Jurnal Keperawatan Stikes Kendal

Priscylia, A.C.R., Linnie, P., Rivelino, S.H. (2014). Hubungan Komunkasi Terapeutik Perawat Dengan Kepuasan Pasien di Ruang Rawat Inap Iriani A RSUP PROF.DR.R.D.KANDO $\mathrm{U}$ MANADO. Universitas Sam Ratulangi Manado.

Prof. Dr. H. M. Burhan Bungin, S.Sos., M.Si., 2017, Metodologi Penelitian Kuantitatif, Jakarta, Kencana

Setiowati, S., Aida, R., Zulfa, Atabaki. (2012). Gambaran Tahapan

KomunikasiTerapeutik

Perawat Terhadap Pasien RSI PKU Muhammadiyah

Pekajangan

Pekalongan.
Siswarini, Lusi Sulfiana, and Kholisotin Agustin, Yuana Dwi. 2019. "Jurnal Kesehatan Primer Website : Http:/ / Jurnal.Polteke skupang.Ac.Id/Index. Php/Jkp The Class of Pregnant Women Influences the Knowledge and Attitudes of Pregnant Women Toward PITC HIV / AIDS Kelas Ibu Hamil Mempengaruhi Pengetahuan Dan Sikap Ibu Hamil Ter." 4(2): 124-29. 